\title{
ƯJ LEHETŐSÉGEK AZ ORVOSTUDOMÁNYBAN AZ EKG JELEK FELDOLGOZÁSA TERÉN
}

\author{
Szilágyi Sándor Miklós, Moldován István Zoltán és Szilágyi László
}

Dolgozatunk bemutat egy saját koncepciójú és kivitelezésú számítógépes ritmusanalizáló rendszert, annak hardver és szoftver elemeit és alkalmazásának potenciális lehetơségeit. A rendszer elvégzi az EKG jel beolvasását, valós idejũ monitorizálását és feldolgozását, automatikus szürését és elemzését, a külơnbơző jelenségek felismerését és oszályozását, a kơvetett paraméterek kiszámítását, illetve tetszóleges megjelenitését. A bemutatott rendszer képes on-line monitorizálási funkció mellett az elmentett regisztrátumok külơnbőzó hosszúságú részének vagy egészének tơbbszintư osztott feldolgozására ritmusanalízis céljából. Ez a rendszer egy kơzponti számítógépből és a páciensekhez kơtődő jelbevitelt és előfeldolgozást biztositó mikrovezérlökből áll.

\section{A rendszer elemei és múködése}

A klinikai és kutatási vonalon egyaránt alkalmazható rendszer lehetővé teszi a beteg EKG jelének napi 24 órán tơrténő mérését, miközben a beteg szabadon mozoghat egy meghatározott területen. $\mathrm{E}$ rendszer elemei egy mikrovezérlős adatgyưjtő kártyát tartalmazó kơzponti számítógép és a betegek derekára erősített mintavételezö készülékek. A beteg mellkasára helyezett érzékelők által szolgáltatott jelet egy nagy kőzős módusú elnyomású differenciál erösitő́t kơvetően egy 80535-os mikrovezérlőbe beépitett A/D konverter digitális formába alakitja. Miután a mikrovezérlő elvégzi az adatok tơmơritését, egy kis hatótávolságú rádió adó-vevő segítségével tơmbơk formájában elküldi a számítógépbe épitett mikrovezérlö memóriajjába, ahonnan megfelelö pillanatokban a PC memóriajába kerül át. Az adattovábbításhoz frekvenciamodulációt alkalmaztunk. Az adatok egyenkénti helyességét Hamming-kódon alapuló bitjavitó algoritmussal, az adatcsomagok integritásának ellenörzését pedig CRC-CCITT szabvány szerint valósitottuk meg. Mivel a mintavételezés nem a számítógép feladata, az adatok biztonságosan elmenthetőek a háttértárolóba. A leirt rendszer elönyei a valós idejû Holter monitorizálás megvalósithatósága viszonylag alacsony előállítási költségek mellett. 


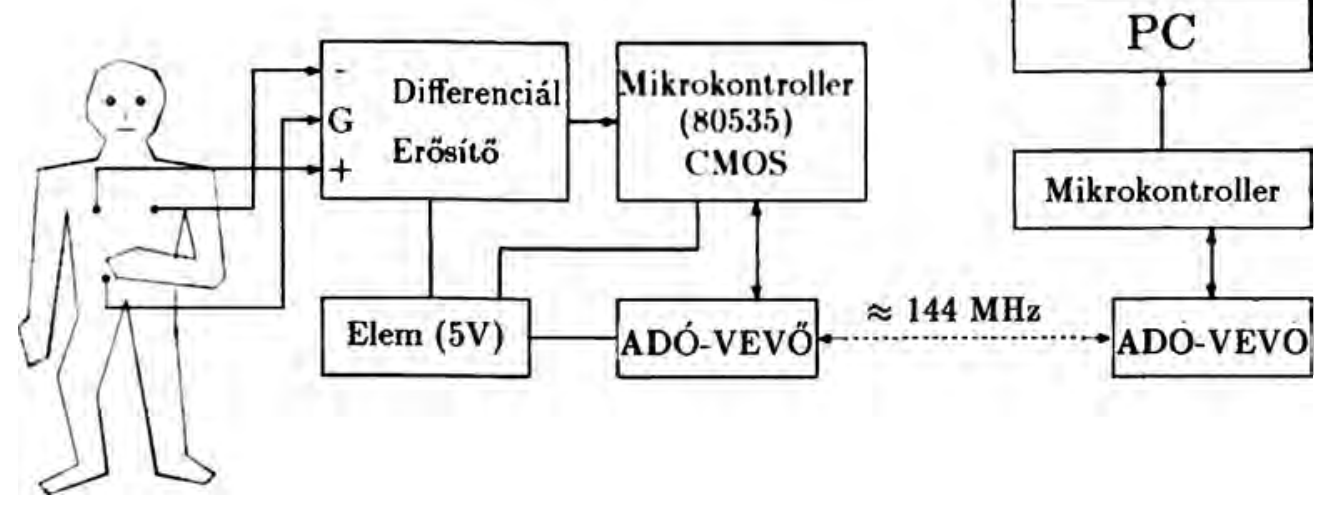

\section{Zajszürés}

A mért jel elválaszthatatlan a zajoktól. Ezek nagy része az EKG jelet beolvasó, az átalakitást elvégzó kártyától, illetve kơzvetlenül a kơrnyezetbőll származnak. Ilyenek például a kơrnyező elektromos hálózatok által okozott $50 \mathrm{~Hz}$-es alapharmonikus és ezek felharmonikusai által gerjesztett zavarok. Sajnos ezek minden kis jelủ elektromos berendezésben jelen vannak és hatásukat megfelelő árnyékolással csak csőkkenteni lehet, teljesen megszüntetni nem. Mivel az $50 \mathrm{~Hz}$-es alapharmonikus benne van a hasznos EKG jel frekvenciaspektrumában, a kiszürését a kơvetkezö müveleteket alkalmazó algoritmussal biztositottuk :

- az EKG jelre elvégezzük az FFT-t, periódusnak tekintve a teljes mérési időtartamot [10],

- a kơrnyező frekvenciatartományt leginkább jellemző amplitudóértékekböl felbecsüljük az aktív EKG jelet alkotó $50 \mathrm{~Hz}$-es frekvenciakomponens amplitúdóját,

- elvégezzük a jel spektrumában a szuikséges módositásokat $(50$ Hz-es komponens amplitúdójának és fázisának módositása),

- az IFFT transzformációval megkapjuk a becsült aktiv EKG jelet.

Az EKG jel ekvivalens áramkőri zaja, valamint a mérörendszerekben létrojơő zajok által elöidézett telítődés okozta zavar szïrése nem lehetséges. A normális mozgás, izom-osszehúzódás vagy légzés okozta zavarokat $[11,12]$ a program az alábbi ábrákon látható módon szäri ki:
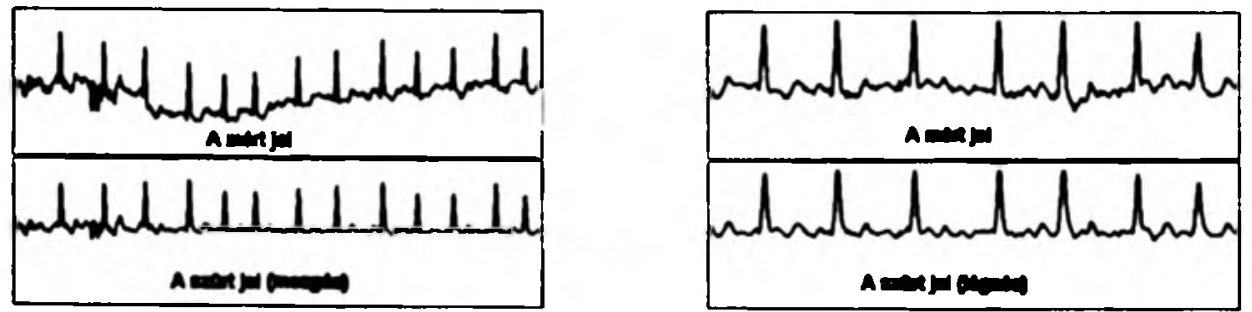

A magas frekvenciájú komponenseket tartalmazó zajok szürése a túlmintavételezést, valamint egy IIR szärőt alkalmaztunk. A zavarok szürésére a sztochasztikus rendszerelméletben kifojlesztett szüröalgoritmus is alkalmazható abban a megkozelítésben, hogy a bemeneti gerjesztő jelet nem ismerjük. A legismertebb ilyen típusú algoritmus a Kálmán szürés, a genetikai algoritmus, illetve a Markov sorokkal való becslés $[2,3,4,5]$ 


\section{Paraméterek becslése és jeltömörítés}

A sziv paramétereinek becslése [6], valamint az EKG jel tőmơrítése megvalósitható a lineáris predikció alkalmazásával. Az EKG jel tơmơritése két, egymástól lényegesen eltérő elven valósitható meg. A hiba nélküli tơmơritést érdemes alkalmazni az EKG jelek archiválására, mivel ez esetben lehetőségünk van az eredeti jel későbbi tanulmányozására. Hátránya, hogy a tơmơritett jel viszonylag sok helyet foglal (az eredeti jel 15-20\%-át). Mobil EKG-vel rendelkező mentők, valamint a hosszú távon megfigyelés alatt levő betegek esetén alkalmazzuk a visszaállitási hibával járó tơmoritő algoritmust. Ez esetben az eredeti jelet csak megkőzelítőleg kapjuk vissza, de egy megfelelő "codebook" adatbázis segítségével a jel megfelelő minőségben visszállitható. A tơmơrítési arány a hiba függvényében változik, általában a tơmơritett jel az eredeti hosszának 1-10\%-át éri el. A hiba maximális értékét úgy kell megválasztani, hogy a kơvetett paraméterek lehetöleg ne változzanak meg.

Jelen pillanatig az EKG jel hiba nélküli tơmơrítési algoritmusán dolgoztunk. Megfelelő kơrültekintés után a paraméterbecslő módszereken alapuló algoritmusokat találtuk a leghatékonyabbaknak, az általunk irt program a lineáris predikción alapszik [1,9]. A lineáris predikció segitségével meghatározhatjuk a kơvetett paraméterek pontos értékét. A program iteratív módon kơzelíti meg a kiszámítandó paraméterek pontos értékeit. Az elsó lépésben egy ritka "hálóval" igyekszik lefedni az elöre meghatározott értelmezési tartományt. A generált megoldások egy kis hányada, amely a legjobb értékeket szolgáltatta, változatlanul megmarad, majd ezeket egymással kombinálva (az eredeti értékek megörzése mellett) létrehoz egy elöre meghatározott számú megoldást. A gradiens módszeren alapuló becslés szolgáltatta megoldások kiegészítik az elöbb kapott megoldáshalmazt.

A "háló" módszer igyekszik a jó megoldások kơzelében kisebb lépéskơzzel választani a megoldásokat. A tapasztalat azt mutatja, hogy kơrülbelül 40 iteráció szükséges az optimálishoz kơzel álló megoldás értékéhez 11 kiszámítandó paraméter esetén. A kísérletek bebizonyitották, hogy a becslési pontosság nơvekszik a kiszámítanđó paraméterek számának az emelésével, valamint a felbontás nơvelésével. A jelre rátevớdŏ zaj érezhető́en rontja a megoldás pontosságát, valamint a kiszámitott paraméterértékek megbizhatóságát. Emiatt sziikségszerü a jel megfelelő szürése a paraméterbecslés előtt.

\section{Az EKG jel feldolgozása}

Az EKG jel analizise a jel értelmezéséböl és a diagnosztika elvégzéséből áll. Az EKG jel értelmezése során szükséges a jel karakterisztikáinak az azonositása. Ez szükségszerü az amplitúdó és a periódus kiszámitásakor. Az EKG modell automatikus felismerése szükségszerüen matematikai módszereket igényel. A megfelelö diagnosztikai pontosság érdekében szükségszerü a kơvetkező jelfeldolgozási feladatok optimális megvalósitása: a jel-zaj viszony javitása, az alapvonal meghatározása, a hullámok kijelólése és a dơntési algoritmus kidolgozása [7,8].

A programunk által alkalmazott feldolgozási módszerek három csoportba sorolhatóak: speciális feldolgozás, grafikus feldolgozás (hisztogram, scattergram. tachogram) és statisztikai feldolgozás. Ezek 
kidolgozása orvosok segitségével és igényei szerint történt. Az algoritmusok kifejlesztéséhez felhasznált regisztrátumokat a marosvásárhelyi III-as klinikán vételeztük e rendszer egy korábbi, jelenleg üzemben levő változatával.

\section{IRODALOM}

[1] G. Nave, A. Cohen - ECG Compression Using Long-Term Prediction, IEEE Trans. Biomed, Eng., vol. 40, SEP 1993, pp 877-885.

[2] Quizhen Xue, Yu Hen Hu, W. J. Tompkins - Neural-Network-Based Adaptive Matched Filtering for QRS detection, IEEE Trans. Biomed. Eng., vol. 39, APR 1992, pp 317-329.

[3] D. A. Coast, R. M. Stern, G. C. Cano, S. A. Briller - An Approach to Cardiac Arrhythmia Analysis Using Hidden Markov Models, IEEE Trans. Biomed. Eng., vol. 37, OCT 1990, pp 826-836.

[4] S. C. Tai - An Extensive Markov System for ECG Exact Coding, IEEE Trans. Biomed. Eng., vol. 42, FEB 1995, pp 230-232.

[5] V. Krishnamurthy, R. Elliott - A Filtered EM Algorithm for Joint Hidden Markov Model and Sinusoidal Parameter Estimation, IEEE Trans. Signal Processing, vol. 43, JAN 1995, pp 353-357.

[6] C. W. Therrien, C. H. Velasco - An iterative Prony Method for ARMA Signal Modeling, IEEE Trans. Signal Processing, vol. 43, JAN 1995, pp 358-361.

[7] G. M. Friesen, T. C. Jannett, M. A. Jadallah, S. L. Yates, S. R. Quint, H. T. Nagle - A Comparison of the Noise Sensitivity of Nine QRS Detection Algorithms, IEEE Trans. Biomed. Eng., vol. 37, JAN 1990, pp 85-97.

[8] Ciuwei Li, Chongxun Zheng, Changfeng Tai - Detection of ECG Characteristic Points Using Wavelet Transforms, IEEE Trans. Biomed. Eng., vol. 42, JAN 1995, pp 21-27.

[9] Kang-Ping Lin, W. H. Chang - QRS Feature Extraction Using Linear Prediction, IEEE Trans. Signal Processing, vol. 36, OCT 1989, pp 1050-1054.

[10] J. M. Rius, R. de Porrata-Doria - New FFT Bit-Reversal Algorithm, IEEE Trans.Signal Processing, vol. 43., APR 1995, pp 991-993.

[11] A. K. Barros, M. Yoshizawa, Y. Yashuda - Filtering Noncorrelated Noise in Impedance Cardiography, IEEE Trans. Biomed. Eng., vol 42, MAR 1995, pp 324-327.

[12] P. Strobach, K. Abraham-Fuchs, W. Harer - Event-Synchronous Cancellation of the Heart Interference in Biomedical Signals, IEEE Trans. Biomed. Eng., vol 41, APR 1994, pp 343-350.

Szilágyi Sándor Miklós, Moldován István Zoltán és Szilágyi László egyetemi hallgatók, Marosvásárhelyi Egyetem

Cím: Str. Liszt Ferenc Nr. 8, 4300 Marosvásárhely, Románia

Telefon: 00-40-65-164490Ｅmail: sziszi@uttgm.ro 